\title{
Struktur Komunitas Ekosistem Pesisir (Lamun dan Mangrove) di Desa Sulamu Nusa Tenggara Timur
}

\author{
Yovita Ariandini ${ }^{1}$, Elok Faiqoh ${ }^{1 *}$, I Gede Hendrawan ${ }^{1}$ \\ ${ }^{1}$ Program Studi Ilmu Kelautan Fakultas Kelautan dan Perikanan Universitas Udayana \\ Jl. Raya Kampus Unud Jimbaran Badung 80361 Bali \\ *elokfaigoh@unud.ac.id \\ DOI: https://doi.org/10.21107/rekayasa.v14i2.10969
}

\begin{abstract}
East Nusa Tenggara Province (NTT) is an archipelago province located in the south of Indonesia has a sea area of 200,000 $\mathrm{km} 2$ (outside ZEEI) in it has marine resources and fisheries that can be developed for the benefit of the community. Seagrass and mangrove ecosystems play an important role for the environment both physically and ecologically. To know the condition of the ecosystem, it is necessary to conduct research on the community structure of seagrass and mangrove ecosystems. This research was conducted in Sulamu Village, Kupang waters in November 2018. Each ecosystem is sampling as many as 3 stations with 3 stations each. From the results obtained, found 7 species of seagrass in salamu village waters namely Halodule pinifolia, Thalassia hemprichii, Cymodocea serrulate, Enhalus acoroides, Halophila ovalis, Cymodocea rotundata, and Halodule uninervis. Seagrass density obtained is the highest $2847 \mathrm{tg} / \mathrm{m} 2$ and the lowest $1392 \mathrm{tg} / \mathrm{m} 2$ with stable community conditions. In mangrove ecosystems found 11 types of mangroves found in sulamu waters namely Avicennia alba, Osbornia octodonta, Bruguiera parviflora, Aegiceras corniculatum, Rhizopora mucronata, Sonneratia alba, Rhizopora apiculata, Xylocarpus granatum, Limnitzera racemosa, Gymnanthera paludosa and Nypa frutican. The mangrove community structure in the waters of Salamu Village is unstable and dominating.
\end{abstract}

Keywords : seagrass, mangrove, community structure

\section{PENDAHULUAN}

Provinsi Nusa Tenggara Timur (NTT) merupakan provinsi kepulauan yang terletak di sebelah selatan wilayah Indonesia memiliki luas wilayah laut $200.000 \mathrm{~km}^{2}$ (di luar ZEEI) di dalamnya memiliki sumberdaya kelautan dan perikanan yang dapat dikembangkan untuk kepentingan masyarakat. Dengan melihat pada kontribusi sumberdaya pesisir dan laut di NTT cukup besar dalam mendukung pertumbuhan ekonomi daerah, maka upaya untuk mengoptimalisasikan pemanfaatan sumberdaya tersebut perlu digali dan diupayakan sebesar-besarnya dengan tetap mempertahankan daya dukung lingkungan pesisir dan laut bagi kepentingan masyarakat serta menambah devisa bagi daerah NTT.

Potensi sumberdaya kelautan dan perikanan yang dimiliki terdiri atas 3 (tiga) kelompok diantaranya sumberdaya dapat pulih (renewable resources); sumberdaya tidak dapat

\section{Article History:}

Received: April, 19 ${ }^{\text {th }}$ 2021; Accepted: June, $27^{\text {th }} 2021$

Rekayasa ISSN: $2502-5325$ has been Accredited by Ristekdikti (Arjuna) Decree: No. 23/E/KPT/2019 August 8th, 2019 effective until 2023 pulih (non-renewable resources dan Jasa-jasa lingkungan (jasling). Sumberdaya dapat pulih seperti mangrove, terumbu karang, padang lamun dan rumput laut (alga), dan sumberdaya perikanan (ikan dan non ikan). Jika dibandingkan dengan dua ekosistem utama lainnya, yaitu ekosistem mangrove dan terumbu karang maka ekosistem lamun memunyai peranan yang tidak kalah penting baik secara fisik mau pun ekologis (Tulungen et al., 2003; Wimbaningrum et al., 2003). Secara fisik padang lamun berperan membantu mengurangi hempasan gelombang dan arus yang menuju pantai, menyaring sedimen yang terlarut dalam air, menstabilkan dasar sedimen, serta penangkap sedimen dan penahan erosi (Fonseca et al., 1982; Kiswara dan Winardi, 1994). Lamun adalah produsen primer dalam ekosistem padang lamun, sehingga merupakan komponen yang

\section{Cite this as:}

Ariandini, Y., Faiqoh, E \& Hendrawan, I.G. (2021). Struktur Komunitas Ekosistem Pesisir (Mangrove dan Lamun) di Desa Sulamu Nusa Tenggara Timur. Rekayasa 14 (2). 207-214 doi: https://doi.org/10.21107/rekayasa.v14i2.10969.

(c) 2021 Yovita Ariandini, Elok Faiqoh, I Gede Hendrawan 
penting di wilayah perairan laut karena menghasilkan oksigen dan materi organik dari hasil fotosintesis. Oleh karena itu, padang lamun digunakan oleh biota laut sebagai tempat mencari makan (feeding ground), pemijahan (spawning ground), dan asuhan (nursery ground) (Bortone 2000). Padang lamun juga berfungsi sebagai penyaring nutrient yang berasal dari sungai atau laut, pemecah gelombang dan arus, serta meningkatkan kualitas air laut dengan membantu pengendapan substrat dan menstabilkan sedimen.

Ekosistem mangrove merupakan ekosistem yang dipengaruhi oleh kondisi perairan yang berubah setiap saat. Hal ini memberikan pengaruh terhadap biota perairan yang hidup berasosiasi dengan ekosistem mangrove tersebut. Ekosistem mangrove juga merupakan bagian yang penting dan menarik dari keseluruhan ekosistem, karena memiliki berbagai fungsi baik secara fisik, ekologi maupun social ekonomi. Fungsi ekologis terutama sebagai habitat yang baik untuk daerah pemijahan (spawning ground), daerah asuhan (nursery ground), dan daerah mencari makan (feeding ground) berbagai macam organisme. Sedangkan secara ekonomis yaitu hasil hutan berupa kayu, hasil hutan kayu seperti madu, obat-obatan, minuman, bahan makanan, tanin, sumber bahan bakar dan lain-lain (arang dan kayu bakar) (Suwondo et al. 2005). Kerusakan hutan mangrove beberapa tahun terakhir mengakibatkan degradasi (penurunan) sumberdaya pesisir.Hal ini diakibatkan oleh pembukaan lahan wisata, pembangunan industri, dan lainnya.

Pentingnya peran dari masing-masing ekosistem tersebut maka sudah seharusnya menjaga kelestariannya sebelum semakin hancur dan berujung hilang. Karena minimnya penelitian tentang tentang struktur komunitas ekosistem pesisir seperti padang lamun dan mangrove maka penulis melakukan penelitian ini untuk mengetahui mengenai informasi keanekaragaman jenis lamun, pola sebaran dan nilai indeks ekologi lamun yang ada di Desa Sulamu, Nusa Tenggara Timur.

\section{METODE PENELITIAN}

Penelitian ini dilakukan di Desa Sulamu Perairan Kupang, Nusa Tenggara Timur. Survei dilakukan pada enam titik di wilayah tersebut. Penelitian ini dilakukan pada bulan November 2018. Peta lokasi penelitian dapat dilihat pada Gambar 1 .

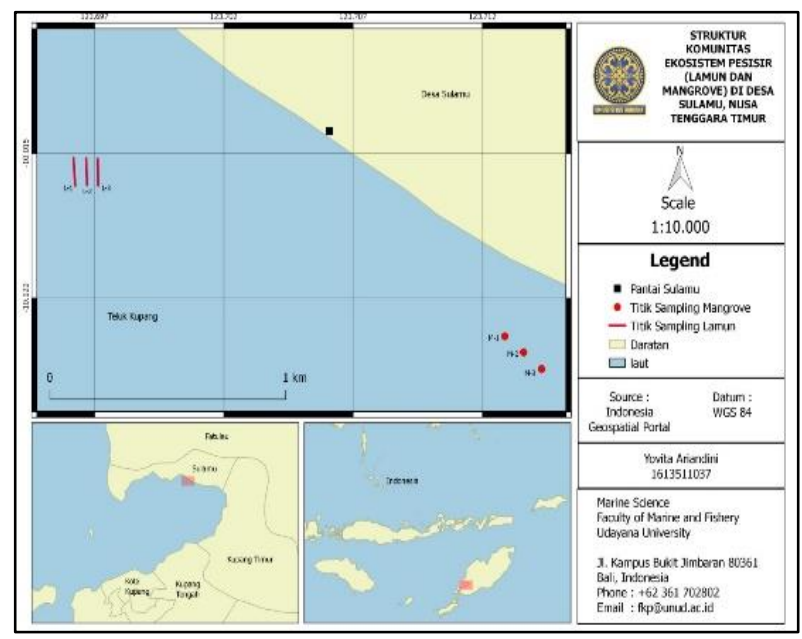

Gambar 1. Peta Lokasi Penelitian

Metode pengambilan data yang digunakan adalah metode random sampling, di mana terdapat 3 stasiun untuk ekosistem lamun dan mangrove. Kategori data yang dikumpulkan meliputi: parameter perairan, kerapatan struktur komunitas lamun dan mangrove. Substrat yang dimaksud merupakan jenis terumbu karang yang hidup di situs penelitian dan substrat tempatnya menempel. Jenis terumbu karang didata berdasarkan bentuk pertumbuhannya. Garis substrat diamati dengan metode transek point-intercept menggunakan pita transek dengan interval pengamatan setiap $0.5 \mathrm{~m}$.

\section{Analisis Data Lamun}

Pengambilan data di lapangan dilakukan dengan cara menghitung tegakan mengamati dan mengidentifikasi jenis lamun menghitung persentase tutupan lamun dengan menggunbakan transek kuadran. Hasil perhitungan kerapatan jenis lamun disajikan secara deskriptif melalui grafik. Setelah diketahui jumlah lamun yang ada dilapangan, angka tersebut dimasukan ke rumus berikut :

$$
D i=\frac{n i}{A}
$$

Keterangan :

$\mathrm{Di}=$ Kerapatan Jenis ke- $\mathrm{I}\left(\mathrm{ind} / \mathrm{m}^{2}\right)$

$\mathrm{Ni}=$ Jumlah individu atau tegakan dalam transek ke-I (ind)

$A=$ Luas total pengambilan sampel $\left(\mathrm{m}^{2}\right)$

Tabel 1. Kategori Nilai Kerapatan Lamun

\begin{tabular}{lcl}
\hline Skala & Kerapatan (ind/m2) & Kondisi \\
\hline 5 & $>175$ & Sangat rapat \\
4 & $125-175$ & Rapat \\
3 & $75-125$ & Agak rapat \\
2 & $25-75$ & Jarang \\
\hline
\end{tabular}




\begin{tabular}{lcl}
\hline Skala & Kerapatan (ind/m2) & Kondisi \\
\hline 1 & $<25$ & Sangat Jarang \\
\hline
\end{tabular}

Frekuensi jenis adalah peluang kehadiran suatu jenis lamun yang ditemukan dalam titik contoh, dengan rumus:

$$
\begin{gathered}
F=\frac{P i}{\sum P} \\
R F_{i}=\frac{\text { Frekuensi jenis } k e-i}{\text { jumlah frekuensi untuk seluruh jenis }} \times 100 \%
\end{gathered}
$$

Indeks nilai penting digunakan untuk menghitung dan menduga keseluruhan dari peranan jenis lamun lainnya dengan rumus sebagai berikut:

$$
\mathrm{INP}=\mathrm{RCi}+\mathrm{Fri}+\mathrm{RDi}
$$

\section{Analisis Data Mangrove}

Pada setiap plot-plot tersebut, di identifikasi jenis vegetasi mangrove yang ada, jumlah individu setiap jenis pada setiap tingkatan vegetasi mangrove. Dari data tersebut dianalisis secara kuantitatif untuk mendapatkan beberapa parameter tumbuhan seperti: Kerapatan (K), Kerapatan Relatif (KR), Frekuensi, Frekuensi Relatif (FRI), Dominansi (DI), Dominansi Relatif (DRI) dan Indeks Nilai Penting (INP). Perhitungan besarnya nilai kuantitif parameter vegetasi, khususnya dalam penentuan indeks nilai penting, dilakukan dengan formula berikut ini (Bengen, 2004) :

a. Kerapatan suatu jenis $\left(D_{i}\right)$ (ind/ha)

$$
D_{i}=\frac{\text { jumlah individu dari jenis } k e-i}{\text { Luas area total pengambilan data }}
$$

b. Kerapatan relatif suatu jenis $\left(R D_{i}\right)(\%)$

$$
R D_{i}=\frac{\text { Jumlah individu dari jenis } k e-i}{\sum \text { umlah individu dari jenis }} \times 100 \%
$$

c. Frekuensi suatu jenis (Fi)

$$
F_{i}=\frac{\text { Jumlah } \text { plot } k e-i}{\Sigma \text { jumlah total plotg }}
$$

d. Frekuensi relatif suatu jenis (FRi) (\%)

$$
R F_{i}=\frac{\text { Frekuensi jenis ke-i }}{\text { jumlah frekuensi untuk seluruh jenis }} \times 100 \%
$$

e. Penutupan jenis (Ci) (m2/ha). Luas penutupan jenis I dalam suatu unit areal tertentu:

$$
C_{i}=\frac{\sum B A}{A}
$$

f. Penutupan relative $\left(R C_{i}\right)(\%)$

Perbandingan antara luas area penutupan jenis I $\left(C_{i}\right)$ dan luas total areal penutupan untuk seluruh jenis

$R C_{i}=\frac{C i}{\sum C} \times 100 \%$

g. Indeks Nilai Penting (INP) (\%)

INP $=R D_{i}+R F_{i}+R C_{i}$
Nilai penting suatu jenis berkisar antara 0 sampai 300. Nilai penting ini memberikan suatu gambaran mengenai pengaruh atau peranan suatu jenis tumbuhan mangrove dalam komunitas.

\section{Analisis Struktur Komunitas}

\section{Indeks Keanekaragaman (Diversity)}

Perhitungan terhadap keanekaragaman mangrove berdasarkan indeks keanekaragaman Shannon-Wiener yang diguanakan untuk menggukur kelimpahan komunitas berdasarkan jumlah jenis spesies dan jumlah individu dari setiap spesies pada suatu lokasi. Semakin banyak jenis spesies, maka semakin beragam komunitasnya. Persamaan yang digunakan sebagai berikut:

$$
\begin{gathered}
H^{\prime}=\sum_{i=1}^{s} p_{i} \ln p_{i} \\
p_{i}=\frac{n_{i}}{N}
\end{gathered}
$$

Kisaran indeks keanekaragaman Shannon-Wiener adalah sebagai berikut:

$\mathrm{H}^{\prime} \leq 2,0$ keanekaragaman rendah

$2,0<\mathrm{H}^{\prime} \leq 3,0$ keanekaragaman sedang

$\mathrm{H}^{\prime}>3,0$ keanekaragaman tinggi

\section{Indeks Keseragaman}

Cara membandingkan indeks keanekaragaman dengan nilai maksimumnya. Semakin seragam penyebaran individu antar spesies maka keseimbangan ekosistem akan semakin meningkat. Persamaan indeks keseragaman sebagai berikut :

$$
\begin{gathered}
E=\frac{H^{\prime}}{H^{\prime} \max } \\
H^{\prime} \text { maks }=\ln S
\end{gathered}
$$

Kisaran indeks keseragaman sebagai berikut:

$0<\mathrm{E} \leq 0,5$ ekosistem tertekan, keseragaman rendah $0,5<\mathrm{E} \leq 0,75$ ekosistem kurang stabil, keseragaman sedang

$0,75<E \leq 1,0$ ekosistem stabil, keseragaman tinggi

\section{Indeks Dominasi Simpson}

Digunakan untuk mengetahui jenis yang paling banyak ditemukan. Persamaan

$$
C=\frac{1}{N^{2}} \sum_{i=1}^{s} n_{i}^{2}
$$




\section{HASIL PEMBAHASAN}

\section{Ekosistem Lamun}

Berdasarkan hasil pengamatan lamun dan identifikasi jenis lamun yang dilakukan di Perairan Desa Salamun ditemukan 7 spesies lamun yang menyebar pada ketiga stasiun. Jenis lamun tersebut yaitu Halodule pinifolia, Thalassia hemprichii, Cymodocea serrulate, Enhalus acoroides, Halophila ovalis, Cymodocea rotundata, dan Halodule uninervis. Kerapatan relative di lokasi penelitian ini menunjukan urutan nilai yang bervariasi. Spesies lamun yang memilki kepadatan tinggi yaitu Halodule pinifolia (90.94\%) pada stasiun 2 dan terendah Halodule uninervis (1.90\%) pada stasiun 2 (Gambar 2).

Nilai kerapatan yang tinggi dapat disebabkan karena jenis substrat yang sesuai dengan pertumbuhan lamun jenis halodule pinifolia. Sebagian besar jenis lamun di Indonesia (Halodule pinifolia, Halodule uninervis, Halophila ovalis, $H$. ovata, Syringodium isoetifolium dan Enhalus acoroides) umumnya tumbuh pada substrat lumpur (Supriati, 2009).

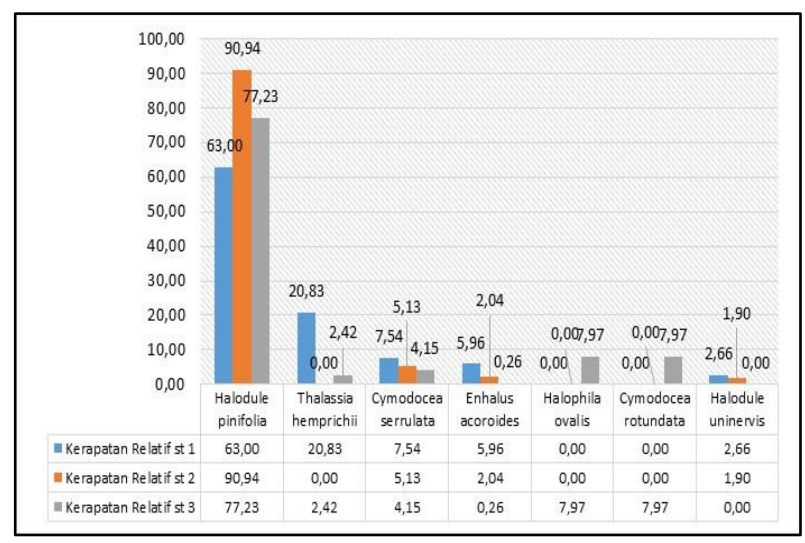

Gambar 2. Kondisi Kerapatan Relatif Ekosistem Lamun

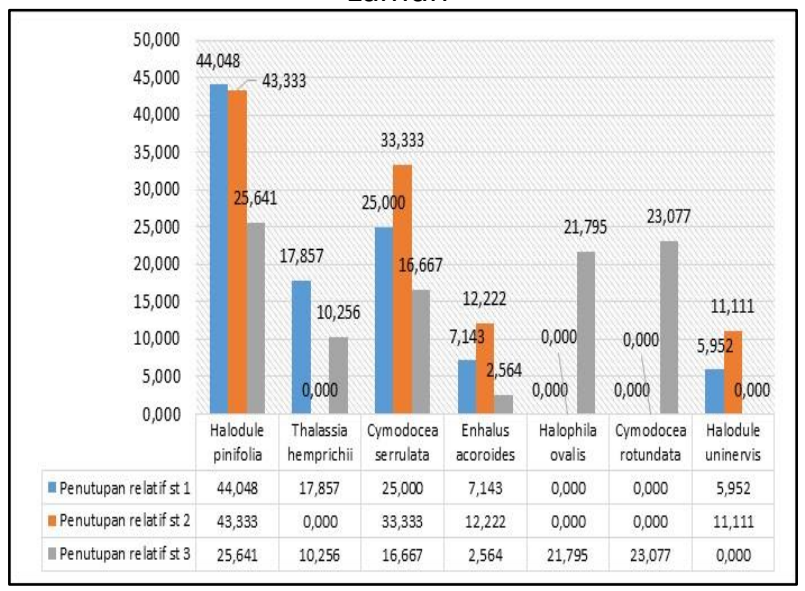

Gambar 3. Penutupan Relatif
Frekuensi relatif adalah perbandingan antara frekuensi speseis ke-I dan jumlah frekuensi untuk seluruh spesies. Hasil penelitian menunjukan frekuensi relativf tertinggi yaitu Halodule pinifolia (37.5\%) dan Cymodocea serrulata (37.5\%), dimana berate bahwa kedua jenis tersebut yang paling umum dijumpai dan memilki sebaran cukup luas di Perairan Salamun. Nilai frekuensi relatif dapat dilihat secara lengkap pada Gambar 3.

Nilai tutupan lamun dapat dilihat dari kriteria kerusakan lamun pada suatu wilayah (Yanti, 2015). Nilai persen penutupan lamun tidak serta merta bergantung dengan nilai kerapatan jenis lamun dan peluang kehadiran lamun saja, melainkan juga dipengaruhi oleh lebarnya helaian jenis lamun karena lebar helaian daun lamun sangat mempengaruhi penutupan substrat, makin lebar daun jenis lamun maka semakin besar kemampuan untuk menutupi substrat di suatu perairan (Yanti, 2015).

Indeks nilai penting lamun di Perairan Salamu menunjukan spesies Halodule pinifolia mencapai $171.77 \%$. Hal ini menunjukan bahwa spesies lamun tersebut dianggap sebagai spesies lamun pembentuk utama komunitas lamun di Peariran Sulamu. Berdasarkan perhitungan indeks nilai penting, spesies yang memiliki indeks nilai penting tertinggi adalah Halodule pinifolia. Spesies Halodule pinifolia walaupun ukuran tubuhnya relative sedang, namun karena kehadirannya yang selalu ada hampir disetiap kuadran dan dalam jumlah yang banyak menunjukkan bahwa spesies ini memiliki pengaruh yang besar terhadap komunitas lamun di Perairan sulamu. Jika kondisi Halodule pinifolia terganggu maka dapat dipastikan spesies lamun lain akan terganggu.

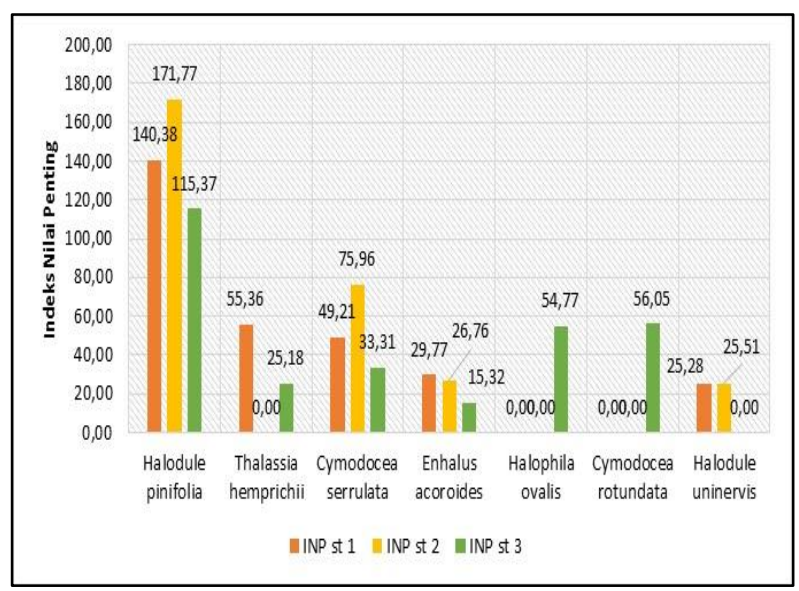

Gambar 4. Indeks Nilai Penting Ekosistem Lamun 


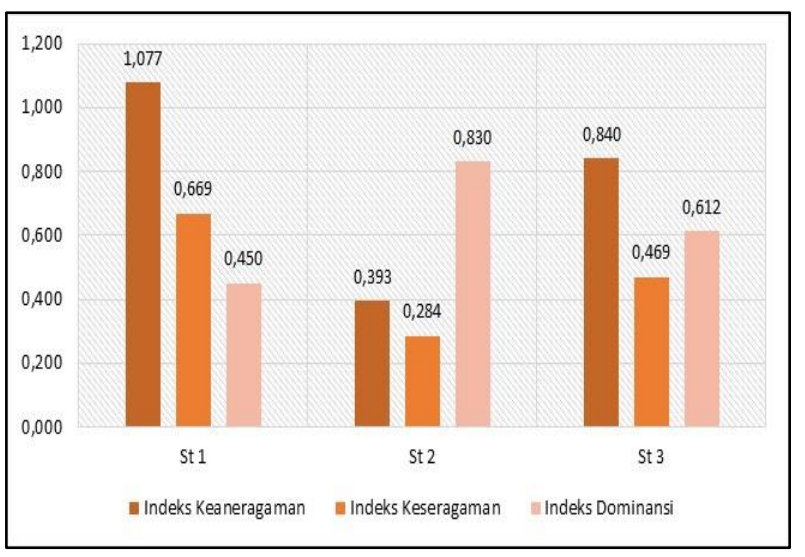

Gambar 5. Indeks Ekologi Ekosistem Lamun

Nilai indeks ekologi lamun di Perairan Desa Salamun didapatkan (Gambar 6). Pada nilai indeks keanekaragaman didapatkan nilai tertinggi yaitu pada stasiun 1 sebesar 1.077 dan terendah stasiun 2 yaitu 0.393 . Nilai indeks keanekaragaman pada stasiun 1 pengamatan tergolong dalam kategori 1 $<\mathrm{H}^{\prime}<3$ dimana memiliki keanekaragaman sedang dengan penyebaran sedang dan kestabilan komunitas sedang. Indeks keanekaragaman tinggi disebabkan oleh jumlah jenis lamun yang ditemukan. Menurut herfina, 2014 suatu komunitas memiliki keanekaragaman yang tinggi apabila semua jenis memilki kelimpahan yang sama atau merata. Nilai indeks keanekaragaman pada stasiun pengamatan 2 dan 3 tergolong dalam kategori $\mathrm{H}^{\prime}<1$ dimana memiliki keankeragaman rendah, penyebaran rendah dan kestabilan komunitasnya rendah. Keanekaragaman menurut Brower et al, (1990) merupakan suatu komunitas yang dimana memilki keanekaragaman jenis tinggi, jika proporsi antar jenis secara keseluruhan sama banyak.

Nilai indeks keseragaman menyatakan kestabilan dari suatu komunitas. Pada stasiun pengamatan nilai tertinggi terdapat pada stasiun 1 sebesar 0.669 dan terendah yaitu 0.284. Indeks keseragaman akan mencapai nilai maksimum jika kelimpahan individu per jenis menyebar secara merata. Nilai indeks keseragaman berkisar antara 0 -1 , semakin besar nilainya maka jumlah individu yang didapatkan semakin seragam. Menurut Wilhm dan Dorris (1968), semakin kecil suatu nilai indeks keseragaman semakin kecil pula keseragaman spesies atau genera dalam komunitas, artinya apabila penyebaran jumlah individu setiap spesies atau genera tidak sama maka ada kecenderungan suatu komunitas menunjukan keseragaman spesies atau genera sama atau tidak jauh berbeda dan dominasi spesies atau genera tertentu kecil sekali atau tidak terdapat dominasi.
Nilai indeks dominansi yang didapat pada stasiun pengamatan nilai tertinggi terdapat pada stasiun 2 sebesar 0.830 dan terendah pada stasiun 1 dengan nilai 0.450 . Nilai indeks dominansi yang mendekati 1 menggambarkan dominansi yang tinggi. Pada stasiun 2 dominansi tergolong kategori D > 0.8 yang artinya dominansi tinggi. Nilai indeks dominansi tinggi menunjukan bahwa telah terjadi ketidakstabilan komunitas dan terdapat dominansi dari spesies lamun tersebut. Menurut Latuconsina et al. (2012), jika ada beberapa jenis dalam komunitas yang memiliki dominansi yang besar maka keanekaragamannya dan keseragamannya rendah.

\section{Ekosistem Mangrove}

Ekosistem hutan mangrove merupakan sumber penghidupan sebagai masyarakat sekitar yang dimana secara sosiologi keberadaan ekosistem hutan mangrove dapat berguna sebagai pelinung dari abrasi, banjir dan tsunami serta sebagai sumber mata pencaharian bagi masyarakat setempat. Ada 11 jenis mangrove yang ditemukan di perairan sulamu yaitu Avicennia alba, Osbornia octodonta, Bruguiera parviflora, Aegiceras corniculatum, Rhizopora mucronata, Sonneratia alba, Rhizopora apiculata, Xylocarpus granatum, Limnitzera racemosa, Gymnanthera paludosa dan Nypa frutican. Pada stasiun 1 ditemukan 6 jenis tumbuhan mangrove yaitu Avicennia alba, Osbornia octodonta, Bruguiera parviflora, Aegiceras corniculatum, Rhizopora mucronata, Sonneratia alba. Pada stasiun 2 ditemukan 5 jenis tumbuhan yaitu Avicennia alba, Rhizopora mucronata, Rhizopora apiculata, Xylocarpus granatum dan Lumnitzera racemosa. Sedangkan, pada stasiun 3 ditemukan hanya 4 jenis tumbuhan yaitu Avicennia alba, Sonneratia alba, Gymnanthera paludosa dan Nypa frutican.

Menurut Zamdial (2016) bahwa terdapatnya tumbuhan nipah pada suatu ekosistem hutan mangrove adalah hal yang biasanya menandakan bahwa lingkungan ekosistem mangrove tersebut merupakan pencampuran antara air tawar dan air laut. Menurut Kartawinata (2013) bahwa palem Nypa fructicans dapat mendominasi hutan mangrove karena terdapat aliran sungai dari hulu hingga muara atau pada tanah yang padat yang dipengaruhi air pasang.

Dari hasil analisis jenis komunitas mangrove pada stasiun 1, 2 dan 3 (Gambar ) nilai kerapatan relative tertinggi pada jenis Avicennia alba sebesar $273,35 \mathrm{ind} / \mathrm{m}^{2}$ dengan kerapatan relative sebesar 
$54,03 \%$ (stasiun 1 ) $281,84 \mathrm{ind} / \mathrm{m}^{2}$ dengan kerapatan relative sebesar $37,01 \%$ (stasiun 2) dan 203,04 ind $/ \mathrm{m}^{2}$ dengan kerapatan relative sebesar $50,98 \%$ (stasiun 3) sedangkan nilai kerapatan terendah yaitu Brugueira parviflora sebesar $20,53 \mathrm{ind} / \mathrm{m}^{2}$ dengan kerapatan relative sebesar 4,03 \% (stasiun 1) Rhizophora apiculata dengan kerapatan sebanyak $80,29 \mathrm{ind} / \mathrm{m}^{2}$ dengan kerapatan relative sebesar $6,78 \%$ (stasiun 2) dan avicennia alba dengan kerapatan sebanyak 203,40 ind $/ \mathrm{m}^{2}$ dengan kerapatan relative sebesar 50,98\%. Menurut Budiman et al. (2006) bahwa distribusi individu jenis mangrove sangat dipengaruhi oleh variasi faktor lingkungan yang berpengaruh sehingga dapat menimbulkan banyaknya jenis mangrove ynag berkumpul pada daerah yang cocok dengan kehidupan jenis mangrove tersebut. Kerapatan jenis berhubungan dengan jarak pohon, jumlah individu yang ditemukan jenis mangrove dan luas lokasi penelitian. Semakin banyak jumlah individu yang didapat maka nilai kerapatan akan semakin tinggi. Menurut Abu bakar (2006) bahwa tingginya kerapatan jenis mangrove disebabkan karena cocoknya habitat hidup jenis mangrove, kurangnya eksploitasi dan kemampuan mangrove beradaptasi dengan lingkungan.

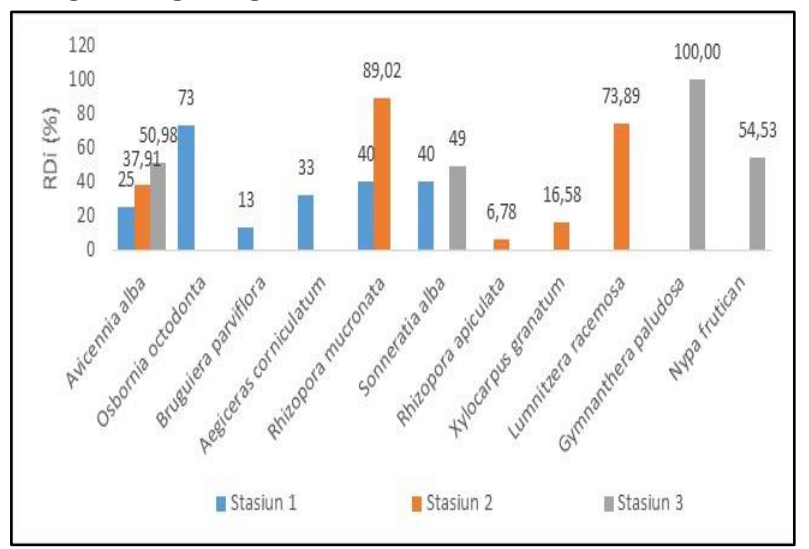

Gambar 6. Kerapatan Relatif Ekosistem Mangrove

Frekuensi jenis tumbuhan mangrove (Gambar 7) yang diteliti terdiri dari tingkatan pohon, anakan dan semai. Keseluruhan stasiun penelitian nilai frekuensi jenis tertinggi yaitu Avicennia alba sebesar 68,06 \% (stasiun 1), 79,55 \% (stasiun 2), Gymnanthera paludosa sebesar 100 \% (stasiun 3). Dari hasil yang diperoleh jenis Avicennia alba sering ditemukan pada 3 stasiun sedangkan Gymnanthera paludosa hanya ditemukan pada 1 stasiun yaitu stasiun 3. Nilai frekuensi jenis mangrove santa dipengaruhi oleh banyaknya suatu jenis yang ditemukan pada setiap kuadran yang ditemukan jenis mangrove sehingga frekuensi kehadiran mangrove akan semakin tinggi. Avicennia alba mnerupakan jenis mangrove yang memiliki nilai frekuensi kehadiran yang sangat tinggi karena terdistribusi pada setiap stasiun. Abu bakar (2006) menyatakan bahwa distribusi individu jenis tumbuhan mangrove sangat dipengaruhi oleh variasi faktor lingkungan sehingga terdapat beberapa jenis mangrove berkumpul dalam jumlah yang banyak pada suatu daerah.

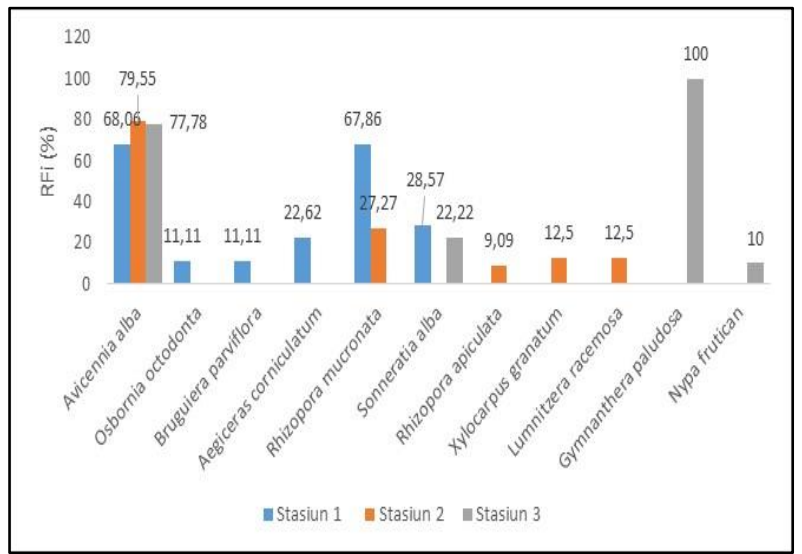

Gambar 7. Frekuensi Relatif Ekosistem Mangrove

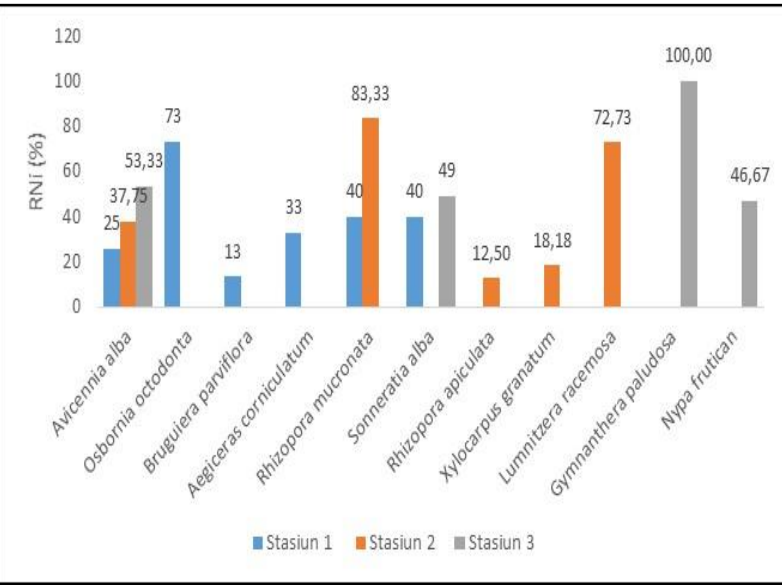

Gambar 8. Penutupan Relatif Ekosistem Mangrove

Nilai penutupan tertinggi terdapat pada jenis mangrove Gymnanthera paludosa dengan penutupan relative $100,0 \%$ dan nilai penutupan relative terendah yaitu Rhizopora apiculata sebesar $12,50 \%$. Nilai penutupan relative sangat berhubungan erat dengan lingkar batang pohon mangrove dari masing-masing jenis mangrove yang dimana semakin besar lingkar batang pohon maka nilai penutupan semakin besar walaupun jumlah jenisnya sedikit. Penutupan relative tertinggi yaitu Gymnanthera paludosa karena jenis ini memiliki diameter batang yang besar. Hasil nilai penting yang diperoleh berdasarkan hasil analisis untuk semua lintasan meiliki jumlah yang sama yaitu 300 . Baik tidaknya pertumbuhan mangrove dalam suatu 
komunitas dapat dilihat dari analisis komposisi vegetasi yang menunjukan besar kecilnya peranan suatu spesies yang didapat dilihat pada Gambar 9.

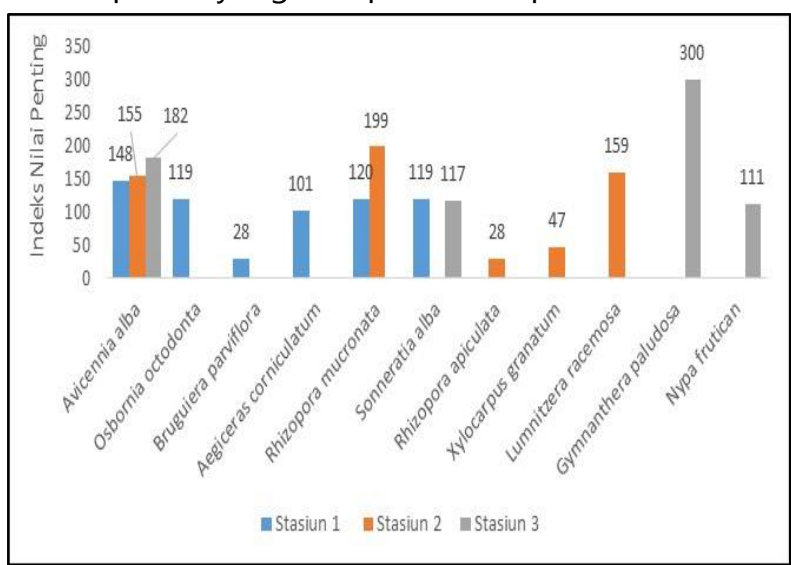

Gambar 9. Indeks Nilai Penting Ekosistem

\section{Mangrove}

Perubahan yang terjadi pada indeks keanekaragaman sangat dipengaruhi oleh jumlah individu dan jumlah spesies dengan hasil indeks keanekaragaman yang diperoleh beragam (Gambar). Hasil indeks keanekaragaman pada stasiun 1, 2 dan 3 termasuk dalam kriteria $\mathrm{H}^{\prime} \leq 2,0$ dengan tingkat keanekaragaman rendah dan tekanan ekologi tinggi. Indeks keanekaragaman $\left(\mathrm{H}^{\prime}\right)$ tertinggi terdapat pada stasiun 1 yaitu sebesar 1,24 yang dimana hal ini terjadi karena adanya salah satu spesies pada stasiun tersebut yang memiliki kelimpahan yang sama. Indeks keseragaman ( $\left.E^{\prime}\right)$ tertinggi terdapat pada stasiun 1 yaitu sebesar 1,34 dengan menunjukan bahwa keseragaman jenis pada lingkungan stasiun 1 dalam kondisi stabil. Sedangkan indeks keseragaman terendah terdapat pada stasiun 3 sebesar 0,32 dan menunjukan bahwa kondisi lingkungan pada stasiun 3 dalam kondisi tertekan dengan keseragaman terendah. Semakin rendah nilai keseragaman maka dapat menunjukan bahwa kondisi lingkungan perairan tersebut dalam kondisi tertekan. Indeks dominansi (C) tertinggi terdapat pada stasiun 1 yaitu sebesar 1,22 yang menujukan bahwa dominansi pada stasiun 1 termasuk tinggi atau terdapat spesies yang mendominasi di perairan tersebut sehingga kondisi lingkungan pada stasiun 1 dalam keadaan tidak stabil dan terdapat suatu tekanan ekologi. Sedangkan nilai indeks domianansi (C) terendah terdapat pada stasiun 3 sebesar 0,34 yang menandakan bahwa dominansi di lingkungan stasiun 3 dominansi rendah atau tidak ada speseis yang terlalu mendominasi pada perairan tersebut dengan kondisi lingkungan stabil sehingga tidka adanya tekanan ekologis terhadap biota di lokasi stasiun 3.

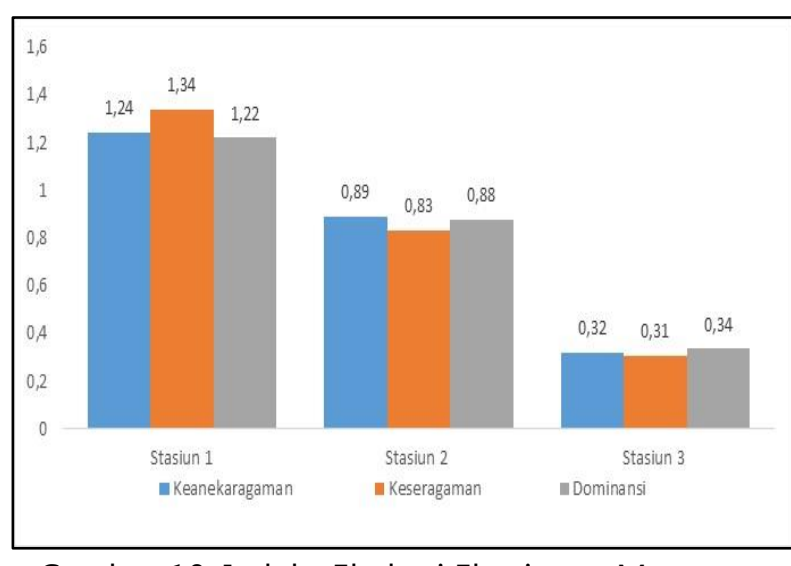

Gambar 10. Indeks Ekologi Ekosistem Mangrove

\section{KESIMPULAN}

Dari hasil yang didapatkan, ditemukan 7 spesies lamun di Perairan Desa Salamu yaitu Halodule pinifolia, Thalassia hemprichii, Cymodocea serrulate, Enhalus acoroides, Halophila ovalis, Cymodocea rotundata, dan Halodule uninervis. Kerapatan lamun yang didapatkan yaitu tertinggi $2847 \mathrm{tgk} / \mathrm{m} 2$ dan terendah $1392 \mathrm{tgk} / \mathrm{m} 2$ dengan kondisi komunitas stabil. Pada ekosistem mangrove ditemukan 11 jenis mangrove yang ditemukan di perairan Desa Sulamu yaitu Avicennia alba, Osbornia octodonta, Bruguiera parviflora, Aegiceras corniculatum, Rhizopora mucronata, Sonneratia alba, Rhizopora apiculata, Xylocarpus granatum, Limnitzera racemosa, Gymnanthera paludosa dan Nypa frutican. Struktur komunitas mangrove pada perairan Desa Salamu tidak stabil dan mendominasi.

\section{DAFTAR PUSTAKA}

Abubakar S. 2006. Studi kelayakan areal pemulihan hutan mangroveberdasarkan tinjaun tipologi pantai di Kecamatan Oba Utara, Kota Tidore Kepulauan Provinsi Maluku Utara [Tesis]. Manado: UNSRAT

Brower JE, Zar JH, and Von Ende ZN. 1990. Field and laboratory methods for general ecology. Wim. C. Brown Co. Pub.Dubuque. Iowa. 237p

Herfina, Ruswahyuni, Bambang S. 2014. Hubungan Kelimpahan Epifauna Yang Berasosiasi Dengan Lamun Pada Tingkat Kerapatan Lamun Yang Berbeda Di Pantai Pulau Panjang, Jepara. Diponegoro Journal Of Maquares. 3 (1): 193-201 
Kartawinata , K., 2013. Diversitas Ekosistem Alam Indonesia. LIPI Press Bekerja Sama dengan Yayasan Pustaka Obor Indonesia, Jakarta. 124 hal.

Latuconsina, H, M. N. Nessa dan RA. Rappe. 2012. Komposisi Spesies Dan Struktur Komunitas Ikan Padang lamun Di Perairan Tanjung Tiram-Teluk Ambon Dalam. Ilmu dan Teknologi Kelautan Tropis, Vol.4 No.1. Hal 35-46.

Supriati, R. 2009. Sea Grasses Diversity and Distribution in Intertidal Area Of Teluk Sepang Selebar Region The City Of Bengkulu: Konservasi Hayati Vol. 05 No. 01 April 2009, hlm. 74-80
Wilhm, J. L. dan T. C. Dorris. 1968. Biological Parameters for Water Quality Criteria. Bio Scientific Publication. London. 18: 477-481.

Zamdial. 2016. Analisa Struktur Komunitas Hutan Mangrove di Desa Pasar Sebelah Kecamatan Kota Mukomuko Kabupaten Mukomuko 